\title{
CONSIDERAÇÕES SOBRE A TEORIA DOS DOIS CIRCUITOS DA ECONOMIA URBANA EM CHAPECÓ-SC
}

\section{CONSIDERATIONS ABOUT THE THEORY OF THE TWO URBAN ECONOMY CIRCUITS IN CHAPECÓ-SC}

\author{
Macleidi Varnier ${ }^{1}$ \\ https://orcid.org/0000-0002-2255-7294
}

Submissão: 29/06/2020 / Aceito: 16/11/2020.

\begin{abstract}
Resumo
Dentro do espaço urbano de algumas cidades dos países subdesenvolvidos percebesse a existência de dois circuitos de produção, distribuição e comércio. O circuito superior: é formado pelos bancos, comércio e indústria de exportação, indústrias modernas, serviços modernos, atacadistas e transportadoras. E o circuito inferior: composto principalmente por formas de produção não-capital intensivo, pelos serviços não modernos, e pelo comércio não moderno e de pequena dimensão. Realizamos neste trabalho uma análise da distribuição dos estabelecimentos econômicos em Chapecó-SC, onde buscamos representar as características e os padrões da esfera econômica que podem ser observados no espaço urbano da cidade. Pelo mapeamento desta distribuição, torna-se possível distinguir dentro do espaço urbano chapecoense as áreas onde predominam cada um dos dois circuitos econômicos e suas estratégias.
\end{abstract}

Palavras-chave: Circuito superior e inferior. Espaço urbano. Economia. Materialização do espaço. Chapecó.

\begin{abstract}
In the urban space of some cities in underdeveloped countries, it is noticed the existence of two production, distribution and trade circuits. The upper circuit is formed by banks, trade and export industry, modern industries, modern services, wholesalers and carriers. And the lower circuit: composed mainly by forms of intensive non-capital production, non-modern services, and small and non-modern trade. In this work, we carried out an analysis of the distribution of economic establishments in Chapecó-SC, where we seek to represent the characteristics and patterns of the economic sphere that can be observed in the urban space of the city. By mapping this distribution, it becomes possible to distinguish in Chapecoense urban space the areas where each of the two economic circuits and their strategies predominate.
\end{abstract}

Keywords: Upper and lower circuit. Urban space. Economy. Materialization of space. Chapecó.

\section{INTRODUÇÃO}

A teoria dos dois circuitos da economia foi proposta por Milton Santos em 1979, em seu livro "O espaço dividido: os dois circuitos da economia urbana dos países subdesenvolvidos". Naquele momento, a obra foi considerada revolucionária, visto que o autor se utiliza de inúmeros dados formulados por ele e seus colaboradores a partir de trabalhos de campo realizados em vários países

\footnotetext{
${ }^{1}$ Graduando em Geografia pela Universidade Federal da Fronteira Sul, campus Chapecó-SC.
} 
Revista Cadernos de Economia

Universidade Comunitária da Região de Chapecó - Unochapecó

Universidade Estadual do Rio Grande do Norte - UERN

do terceiro mundo. Até então, os espaços urbanos das cidades do terceiro mundo eram analisados baseando-se em conceitos formulados em países europeus, o que resultava em métodos importados para se compreender a realidade e conduzia a uma abordagem em moldes quantitativos que ignorava as diferenças de formação histórica entre contextos de mundo opostos. O que culminava na ideia errônea de que o desenvolvimento econômico dos países periféricos é apenas questão de tempo, deixando de considerar as relações de dependência e o modo de organização voltado a interesses exógenos nestes países. Neste sentido, esta obra passa a interpretar o espaço urbano nos países subdesenvolvidos observando as especificidades que ocorrem nestes países.

Chapecó é uma cidade localizada no oeste de Santa Catarina (Figura 1), é considerada uma capital regional de nível b pelo IBGE (Instituto Brasileiro de Geografia e Estatística), exercendo influência sobre mais de uma centena de municípios do oeste de Santa Catarina, Sudoeste do Paraná e noroeste do Rio Grande do Sul. Possui uma população total estimada de 224.013 habitantes (em 2020) e taxa de urbanização de 91,6\% (2010), o município se evidencia como o principal centro urbano e polo econômico do Oeste Catarinense, devido principalmente à presença de significativas unidades do seguimento de produtos alimentícios (especialmente de origem suína e avícola) e de diversas empresas com atividades de apoio à produção agroindustrial, além de uma ampla gama de atividades econômicas e de serviços privados e públicos. (VILLELA et al., 2017; IBGE, 2020).

O município foi fundado ao fim da guerra do contestado, em 1917, para administrar uma grande área do oeste catarinense. Com o passar dos anos, outros adensamentos populacionais emanciparam-se ao status de município nesta região, o que acabou reduzindo a área de responsabilidade administrativa de Chapecó. Desde os primeiros adensamentos populacionais, estiveram presentes as desigualdades socioespaciais e a 'aptidão' agrícola na cidade. Nos primórdios do município, a base econômica se baseava na agricultura de subsistência associada a pequenos frigoríficos; as madeireiras também foram significativas neste momento, perdendo gradativamente a sua importância com o grande desflorestamento e a consequente falta de matériaprima. A partir da década de 1970 grandes frigoríficos instalaram-se na cidade, o que a tornou um centro regional na produção de carnes. Mais recentemente, nas últimas décadas, a ampliação do setor de comércio e serviços, o desenvolvimento de hospitais e clínicas de saúde, a instalação de importantes universidades, o advento de voos regulares à capitais nacionais no aeroporto municipal e a ascensão do time de futebol consolidaram a centralidade de Chapecó em relação a municípios da Mesorregião Grande Fronteira do Mercosul. (KAISER, 2012. MORETTO e BRANDT, 2019. NASCIMENTO, 2017.). 


\section{Revista Cadernos de Economia}

Universidade Comunitária da Região de Chapecó - Unochapecó

Universidade Estadual do Rio Grande do Norte - UERN

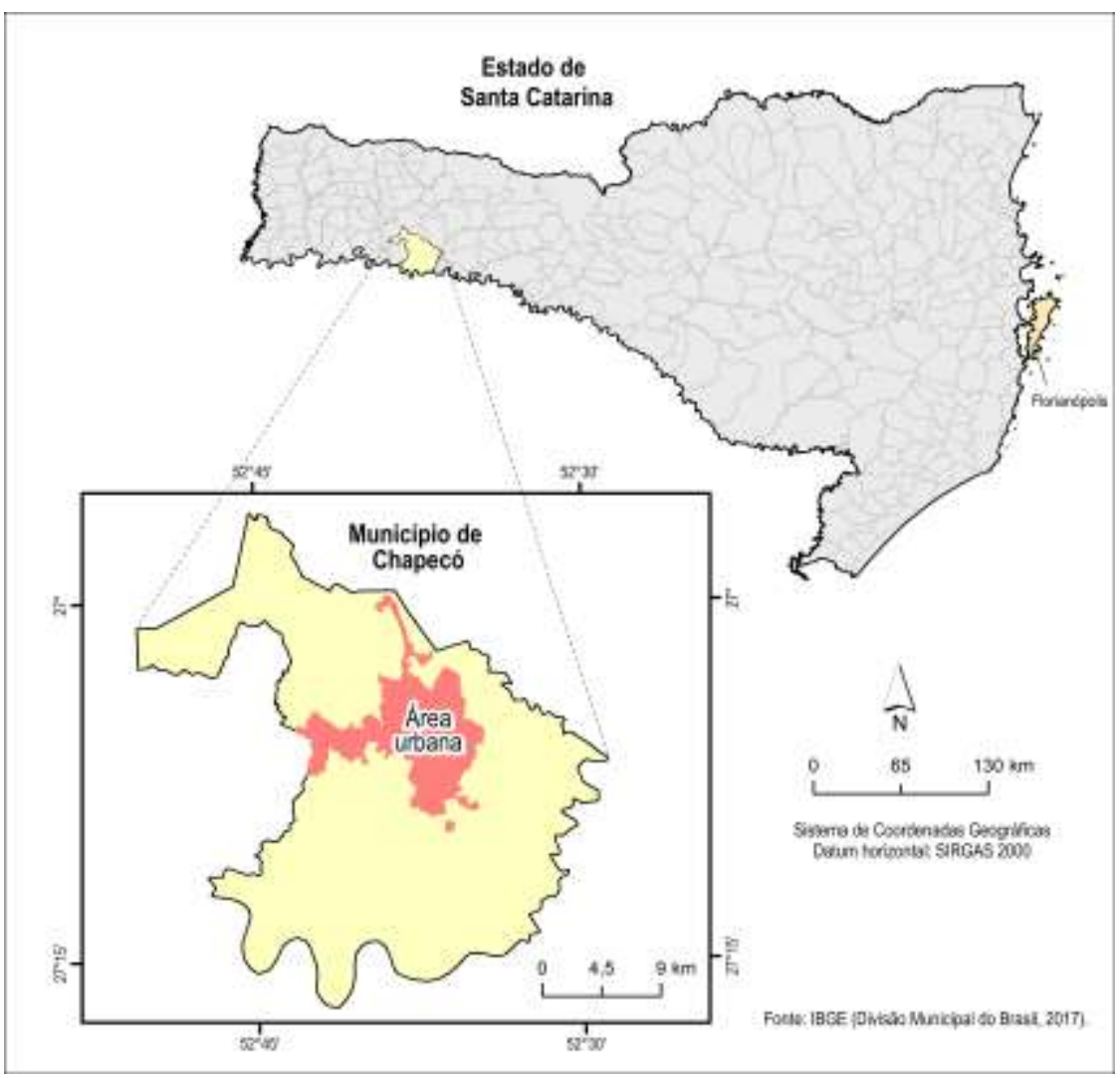

Figura 1: Mapa de localização do município de Chapecó-SC.

A pesquisa desenvolveu-se utilizando de uma abordagem quali-quantitativa. A metodologia do trabalho foi realizada nas seguintes etapas: i) revisão da obra "O espaço dividido: os dois circuitos da economia urbana dos países subdesenvolvidos" do professor Milton Santos e leitura de estudos de caso envolvendo esta temática. Consulta a materiais que tratam da constituição histórica de Chapecó; ii) realização de inúmeros trabalhos de campo para se compreender características da formação material do espaço urbano chapecoense; iii) elaboração de mapas buscando espacializar a distribuição dos principais centros de atividades econômicas em Chapecó, e; iv) Análise das características da distribuição espacial dos estabelecimentos econômicos.

A seguir, apresentaremos as principais características da teoria em questão, seguido da análise dos centros comerciais, industriais e de serviços da cidade a partir desta teoria. Por último, expomos as considerações finais.

\section{A TEORIA DOS DOIS CIRCUITOS DA ECONOMIA URBANA}

O conjunto de ideias que fazem parte da teoria dos dois circuitos da economia foram pensadas para explicar as realidades urbanas observadas nos países do dito terceiro mundo. Milton Santos 


\section{Revista Cadernos de Economia}

Universidade Comunitária da Região de Chapecó - Unochapecó

Universidade Estadual do Rio Grande do Norte - UERN

aponta que uma das maiores diferenças entre países considerados desenvolvidos e subdesenvolvidos, é que nestes últimos há a existência de duas classes de indivíduos. Uma que tem acesso permanente aos bens de consumo e serviços, com renda elevada (minoria das pessoas). E, outra com as mesmas necessidades de consumo de bens e serviços, porém sem as condições de satisfazê-las (maioria da população). Essas diferenças são as causas e os efeitos da existência de dois circuitos de produção, distribuição e consumo dos bens e serviços nas cidades. Sendo que as duas classes não consomem os mesmos produtos e serviços, e também não possuem acesso ao crédito da mesma forma (Figura 2 e 3). Já nos países desenvolvidos, a desigualdade social entre as classes de indivíduos é menos significativa.

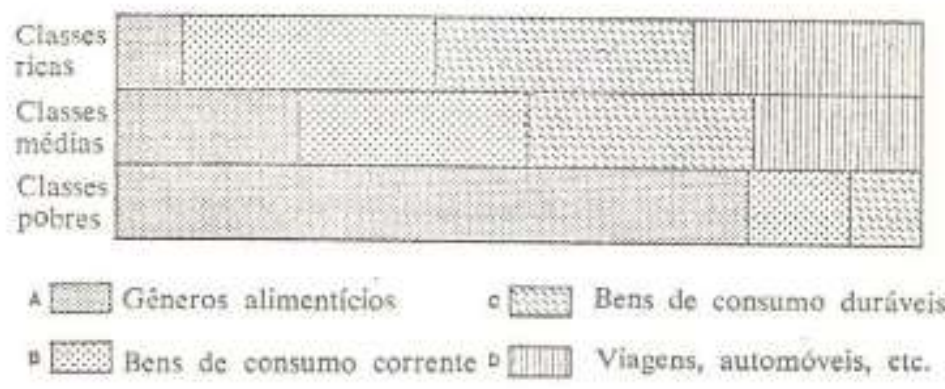

Figura 2: Possibilidade de crédito às classes econômicas relacionado ao tipo de consumo. (SANTOS, 1979, p 207)

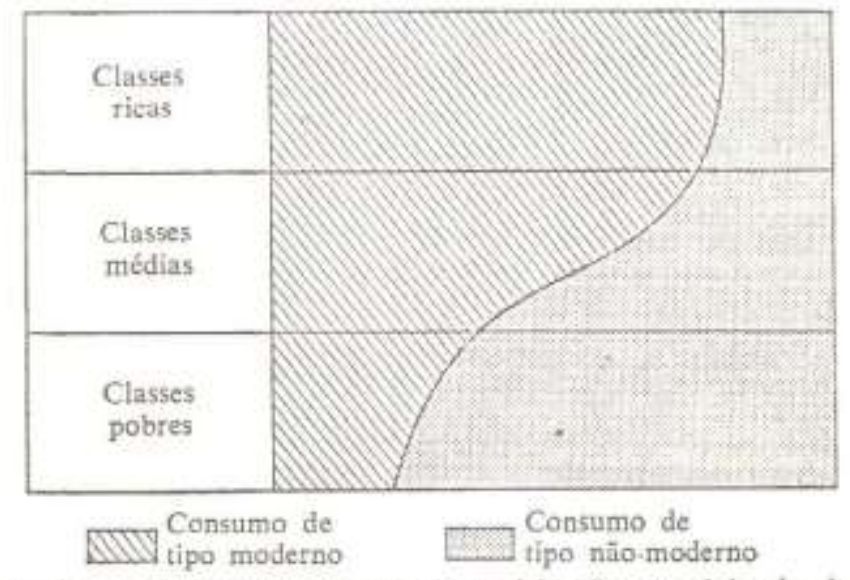

Fig. 2 - Distribuiçăo da renda e participaçăo nos dois circuitos. 


\section{Revista Cadernos de Economia}

Universidade Comunitária da Região de Chapecó - Unochapecó

Universidade Estadual do Rio Grande do Norte - UERN

Santos define o circuito superior como sendo formado pelos bancos, comércio e indústria de exportação, indústria urbana moderna, serviços modernos, atacadistas e transportadoras. E o circuito inferior sendo constituído por modos de fabricação não capital intensivo, pelos serviços não modernos fornecidos a varejo e pelo comércio não moderno e de pequena dimensão. (Figura 4 e 5).

\section{CARACTERISTICAS DOS DOIS CIRCUITOS DA ECONOMIA URBANA DOS PAISES SUBDESENVOLVIDOS}

\begin{tabular}{|c|c|c|}
\hline & CIRCUITO SUPERIOR & CIRCUITO INFERIOR \\
\hline $\begin{array}{l}\text { Relaçóes com a elientela } \\
\text { Custos fixos } \\
\text { Publicidade } \\
\text { Reutilizaçăo dos bens } \\
\text { Overhead capital } \\
\text { Ajuda governamental } \\
\text { Dependênein diretn do } \\
\text { exterior }\end{array}$ & $\begin{array}{l}\text { capital intensivo } \\
\text { burocrática } \\
\text { importantes } \\
\text { reduzido } \\
\text { dominante } \\
\text { grande quantidade e/ou } \\
\text { alta qualidade } \\
\text { fixos (em geral) } \\
\\
\text { bancírio institucional } \\
\text { reduzida por unidade, } \\
\text { mas importante pelo } \\
\text { volume de negócios } \\
\text { (exceçáo produtos de luxo) } \\
\text { impessoais e/ou eom } \\
\text { papeis } \\
\text { importantes } \\
\text { necessíria } \\
\text { rula } \\
\text { indispensível } \\
\text { importante } \\
\text { grande, atividade voltada. } \\
\text { para o exterior }\end{array}$ & $\begin{array}{l}\text { trabalho intensivo } \\
\text { primitiva } \\
\text { reduzidos } \\
\text { volumoso } \\
\text { não obrigatório } \\
\text { pequena quantidade, } \\
\text { qualidade inferior } \\
\text { submetidos à discussão } \\
\text { entre comprador o } \\
\text { vendedor (haggling) } \\
\text { pessoal nấ-institucional } \\
\text { elevada por unidade, } \\
\text { mas pequena em relaçāo } \\
\text { ao volume de negócios } \\
\text { diretas, personalizadas } \\
\text { despreziveis } \\
\text { nula } \\
\text { freqüente } \\
\text { dispensável } \\
\text { nula ou quase nula } \\
\text { reduzida ou nula }\end{array}$ \\
\hline
\end{tabular}

Figura 4: Característica dos dois circuitos da economia urbana. (SANTOS 1979, p 34.). 
Revista Cadernos de Economia

Universidade Comunitária da Região de Chapecó - Unochapecó

Universidade Estadual do Rio Grande do Norte - UERN

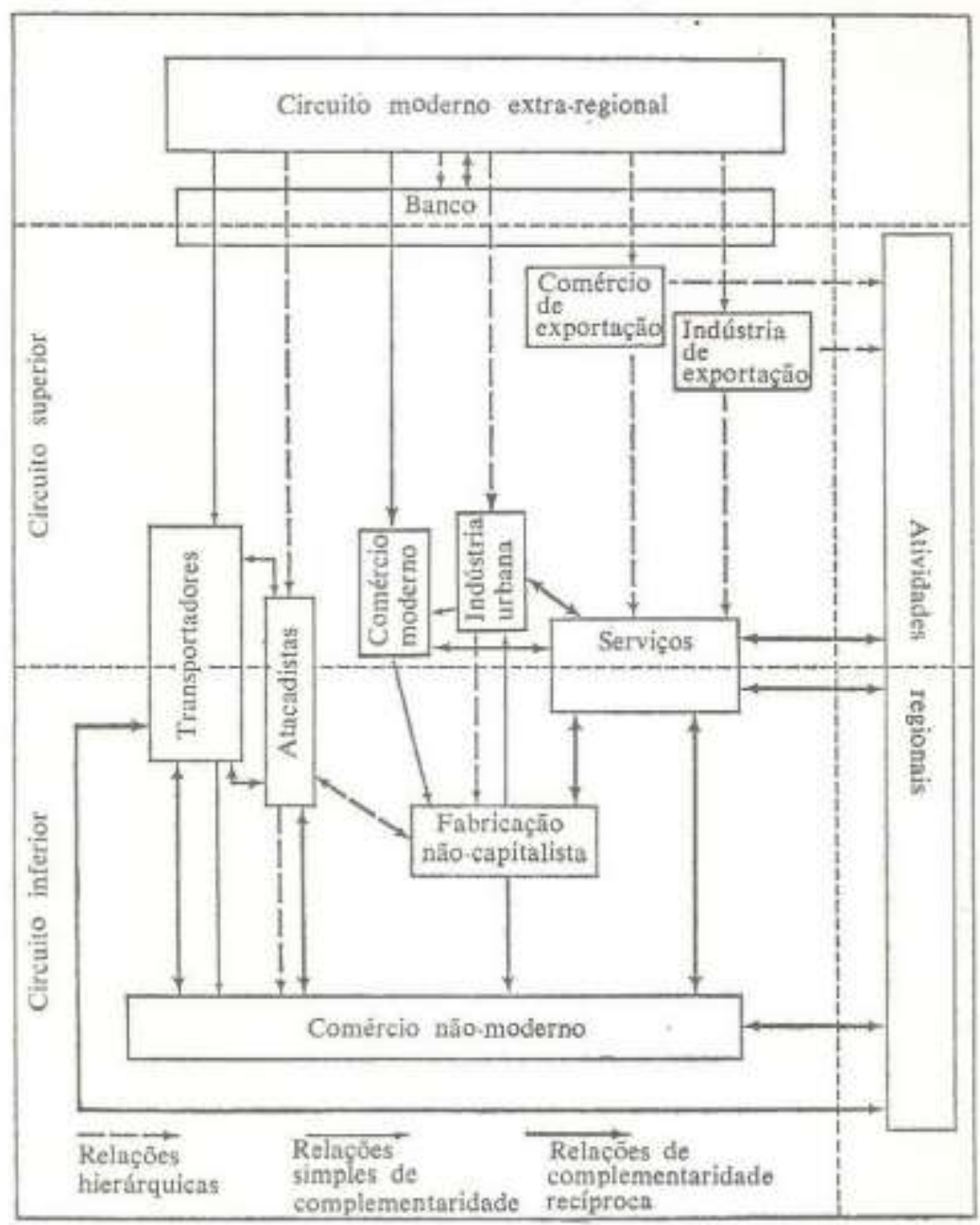

Figura5: Elementos dos dois circuitos da economia urbana dos países subdesenvolvidos. (SANTOS, 1979, p 31.).

O circuito superior comercializa produtos que têm origem principalmente em lugares longínquos. Sendo controlado nos países subdesenvolvidos geralmente por agentes externos, devido a estes terem maior facilidade em adquirirem crédito. As empresas estrangeiras investem em setores que lhes são interessantes, segundo as características de cada país. Concentrando-se principalmente na extração de matérias-primas e produção de mercadorias que poderão ser vendidas para indivíduos com maior poder de renda. Outro elemento importante é o aparelho bancário internacional, que controla direta ou indiretamente o circuito superior da economia. Os bancos internacionais dão preferência por financiar o comércio, indústrias e produção agrícola que é destinada à exportação. Em escala regional, nacional e internacional, os bancos possuem a tendência de movimentar dinheiro de locais pobres para locais ricos; ao mesmo tempo, os bancos 
Revista Cadernos de Economia

Universidade Comunitária da Região de Chapecó - Unochapecó

Universidade Estadual do Rio Grande do Norte - UERN

captam dinheiro em escala internacional para investir em regiões e áreas da produção destinadas à exportação.

As indústrias nos países subdesenvolvidos apresentam dependência/servidão tecnológica em relação ao centro do sistema capitalista. A evolução constante da técnica conduz a uma dependência crônica. Entretanto, a modernização tecnológica não atinge todos os setores da indústria e lugares da mesma forma e a materialidade necessária para a produção industrial com frequência vem de lugares longínquos. As multinacionais instaladas no terceiro mundo dependem em grande medida para sua atuação de áreas da produção, pesquisa e desenvolvimento que empregam pessoas no país de origem da empresa ou em outros territórios do planeta. Além disso, nos países do terceiro mundo há o emprego de estrangeiros em áreas da indústria que demandam de conhecimento, resultando em uma desigualdade nos salários de pessoas consideradas qualificadas e não qualificadas. Os empregos em áreas do circuito superior onde há alto grau de tecnificação geram ao mesmo tempo o não-emprego, tendo em vista que os monopólios possuem capacidade reduzida de criar empregos e absorver força de trabalho. Neste sentido, a modernização tecnológica gera disparidades sociais e econômicas crescentes.

O comércio e serviços do circuito inferior tende a ter suas atividades mais condicionadas ao nível do local, este circuito tem características de ser original e complexo, tendo capacidade de recuperar e reaproveitar materiais nas suas atividades. Para se considerar o que é uma pequena empresa no circuito inferior, não se pode analisar apenas o número de funcionários, mas também as técnicas, a organização e a inserção na economia. Santos salienta a grande capacidade do circuito inferior em empregar mão de obra, sendo grande parte desta descendente do êxodo rural seguido de concentração urbana. Entretanto, cabe destacar que grande parte do emprego da mão de obra se dá de modo informal, em que a maioria dos trabalhadores se veem em situação de subemprego; além de o número médio de trabalhadores por estabelecimento ser baixo.

O modo do sistema de negócios no circuito inferior é arcaico, as vendas se dão majoritariamente de forma direta e o trabalho doméstico, autônomo e familiar é bastante difundido neste circuito. Outras peculiaridades são de que geralmente o espaço utilizado para as atividades é de pequena dimensão, os estoques são reduzidos, há o trabalho na própria habitação e a presença constante de vendedores de rua.

Existe a grande necessidade por dinheiro líquido, Milton menciona que no circuito inferior movimenta-se um montante total de dinheiro líquido grande, entretanto a soma de cada transação é pequena. A necessidade constante de crédito obriga os trabalhadores a unirem-se em formas de 
Revista Cadernos de Economia

Universidade Comunitária da Região de Chapecó - Unochapecó

Universidade Estadual do Rio Grande do Norte - UERN

autofinanciamento. O crédito bancário oferece uma pequena parcela do crédito consumido no circuito inferior, muito em função de seus componentes considerarem perigoso recorrer ao crédito bancário. Tendo que em muitas vezes a concessão de empréstimos se dá de forma pessoal dentro do circuito inferior, onde o credor acaba dependente do devedor e é possível um alto valor de ganho (juros); resultando em uma generalização do endividamento principalmente entre os pobres. Quanto mais se direciona para as esferas mais baixas do circuito inferior, a margem do lucro tende a aumentar. O preço dos produtos e serviços podem sofrer variações dependendo das necessidades dos sujeitos e das variações que acontecem na vida do circuito inferior. Sendo que este circuito é auto-inflacionário e seu comportamento é uma resposta direta a demanda local, se adaptando às necessidades locais vigentes. Dentro do circuito inferior também há grande fluidez de emprego, devido às adaptações que se fazem necessárias. O geógrafo nos afirma: "Não se muda de atividade no decorrer de um ano, ou mesmo de uma semana, ou de um dia, porque é emocionante, mas porque é necessário adaptar-se rapidamente a uma demanda muito sensível às oscilações de conjunturas." (SANTOS, 1979,p. 199.). O circuito inferior muitas vezes fornece réplicas de mercadorias das grandes empresas, implicando em uma mudança da estrutura de consumo. Executando as atividades empregando a criatividade e o modo autodidata na elaboração de reparos de mercadorias pertencentes aos setores modernos. Sendo o circuito inferior um meio caminho entre atividade secundária e terciária, tendo um limite intransponível em relação ao artesanato e se adaptando a modernização.

O conceito de efeito-demonstração é apresentado com fim de representar a influência e capacidade da propaganda e publicidade em moldar e criar gostos. Destacando que o circuito superior se utiliza da divulgação de produtos com fim de criar um imaginário buscando impulsionar o consumo. $\mathrm{O}$ emprego de anúncios em rádios, redes de TV e mais recentemente internet, são as táticas principais. Enquanto que no circuito inferior a propaganda é baseada nas relações pessoais, no boca a boca. É muito comum em pequenas lojas e prestadoras de serviços encontrar letreiros como forma de divulgação das atividades, um modo artesanal e tradicional de se promover o trabalho.

Finalmente, há a coexistência no espaço do que se chama de materialidade tradicional e moderna, evidenciando-se que os dois circuitos criam materialidade ao mesmo tempo. Destaca-se o conceito de macrocefalia, que concerne a concentração das infraestruturas promovidas pelo estado nas metrópoles em que se encontram as grandes empresas; neste sentido, existe uma desigualdade tecnológica espacial com tendência a concentração. O autor expõe também a ideia de colonização 
Revista Cadernos de Economia

Universidade Comunitária da Região de Chapecó - Unochapecó

Universidade Estadual do Rio Grande do Norte - UERN

interna, onde as metrópoles concentram para si a presença das grandes empresas e das infraestruturas, subordinando dentro da rede urbana o papel das outras cidades.

\section{CARACTERÍSTICAS ECONÔMICAS DE CHAPECÓ-SC}

A composição étnica da população chapecoense é resultado de sua história de ocupação. Havendo os indígenas, que são as populações tradicionais deste espaço; os caboclos que descendem de relações entre os primeiros imigrantes europeus (principalmente espanhóis e portugueses) e as populações tradicionais; e a partir principalmente de 1950, a migração de descendentes de imigrantes alemães, italianos e poloneses do Rio Grande do Sul, que chegaram ao oeste catarinense em busca de áreas de terra para a produção agrícola e a prática de um modelo econômico de subsistência. É a partir deste cenário de ocupação que se desenvolve a constituição do município. (RADIN, 2015.).

A colonizadora Bertaso foi a responsável pelo loteamento urbano inicial e a definição do centro urbano da cidade. A ação da colonizadora é significativa para se compreender os embates entre os grupos de indivíduos. A monetização da terra resultou em uma apropriação desigual do solo urbano, as áreas mais próximas ao centro tornaram-se moradias restritas aos grupos mais abastados financeiramente, devido ao custo da terra; enquanto os grupos mais vulnerabilizados ocuparam as áreas periféricas da cidade. A criação do bairro São Pedro pela colonizadora é emblemática neste contexto, trata-se de um bairro que quando foi criado encontrava-se desconexo da malha urbana e com infraestruturas que até hoje são precárias, o intuito de sua criação foi para a alocação de pessoas consideradas indesejadas que vagavam pela cidade e afetavam a imagem de progresso que a colonizadora buscava se associar. Esse modo de vida urbano que se intensifica após a colonização pelos descendentes de imigrantes europeus, entra em rota de colisão com o modo de vida indígena e caboclo, que historicamente possui uma relação diferente com o espaço. O desmatamento de áreas de matas nativas para se produzir lavouras e comercializar madeira em larga escala também significou em uma diminuição considerável daquela que era a base da economia dos habitantes tradicionais, a floresta. (NASCIMENTO, 2015.).

A partir da década de 1970, importantes frigoríficos associados ao abate de galináceos e suínos instalam-se na cidade. A presença desta importante fonte de emprego fez com que o município visse um aumento significativo de sua população. As grandes agroindústrias concentramse na região oeste do perímetro urbano, em que se destaca o bairro Efapi. Tal bairro é formado por 


\section{Universidade Comunitária da Região de Chapecó - Unochapecó} Universidade Estadual do Rio Grande do Norte - UERN

um conjunto de loteamentos que foram criados a partir da década de 1970 com o intuito principal de servir de moradia para trabalhadores das agroindústrias. Atualmente o bairro Efapi é o mais populoso da cidade e abriga muitos trabalhadores e estudantes das universidades próximas. As agroindústrias ainda são a base da economia municipal e grande fonte de empregos. (FACCO, J. et al, 2014. DALMORA e SCHERMA, 2019.).

Nas últimas décadas a cidade presenciou um aumento populacional significativo e consolidou-se como a cidade mais importante da rede urbana do oeste catarinense. $\mathrm{O}$ setor de serviços, comércio e industrias de complementariedade ao setor agroindustrial tiveram um crescimento significativo. No ano de 2000, criou-se o distrito industrial Flávio Badissera, onde hoje encontram-se pequenas e médias empresas que sobretudo atuam criando e fornecendo equipamentos para agroindústrias. ${ }^{2}$ Chapecó detém uma posição de centralidade em relação a cidades do oeste de Santa Catarina, noroeste do Rio Grande do sul e sudoeste do Paraná. Aproximando-se daquilo que Milton Santos nomeia de macrocefalia, onde percebesse que a população, as infraestruturas e os estabelecimentos econômicos e estatais são muito mais significativos em Chapecó que em cidades vizinhas. Resultando que o montante total de investimentos em grande medida acaba direcionando-se à cidade. (NASCIMENTO, 2015.).

Atualmente no espaço urbano chapecoense percebesse claramente a presença de dois centros comerciais bem definidos. No Centro da cidade e bairros adjacentes: concentrando sobretudo estabelecimentos comerciais e de serviços. E no bairro Efapi: também havendo estabelecimentos comerciais e de serviços voltados principalmente à população do próprio bairro. Percebesse também um padrão de ocupação dos estabelecimentos econômicos ao longo das vias principais que cortam a cidade, onde o constante trânsito destas vias é a principal determinante de ocupação. Devemos destacar o distrito industrial Flávio Baldissera, que fica ao Sul do limite urbano e com acesso à BR480, sendo uma área de ocupação recente possuindo potencialidade de crescer ainda mais. As agroindústrias, hospitais e universidade também se apresentam como importantes determinantes locacionais dos estabelecimentos econômicos (Figura 6).

2 Lei Municipal No 4228, de 20 de novembro de 2000. 


\section{Revista Cadernos de Economia}

Universidade Comunitária da Região de Chapecó - Unochapecó

Universidade Estadual do Rio Grande do Norte - UERN

\section{LOCALIZAÇÃO DOS CENTROS COMERCIAIS, DE SERVIÇOS E INDUSTRIAIS EM CHAPECÓ-SC}

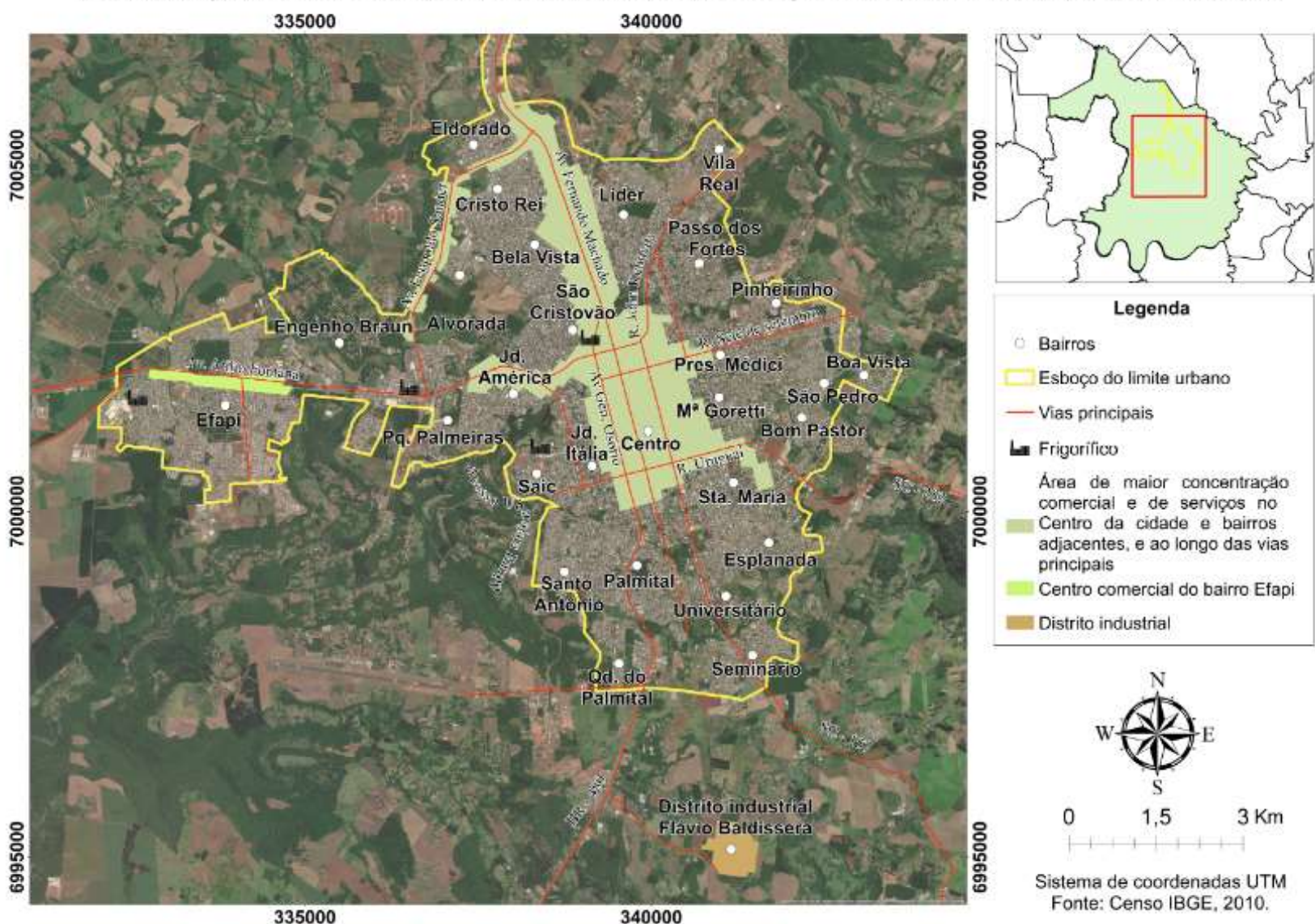

Figura 6: Localização dos centros comerciais, de serviços e industriais em Chapecó-SC

\section{O CENTRO COMERCIAL E DE SERVIÇOS DO CENTRO E BAIRROS ADJACENTES}

O centro de Chapecó e bairros adjacentes é a região do município onde historicamente concentraram-se as elites econômicas. A definição de um centro dotado de objetos que atraem fluxos (como igrejas, praças, comércios e serviços, estabelecimentos estatais; etc.) agrega valor a este espaço em relação aos demais. O preço do solo urbano é muito mais elevado no Centro da cidade quando comparado aos outros bairros, o que resultou no desenvolvimento de um processo de segregação socioespacial. Para obter uma moradia na porção central da cidade é necessário que o indivíduo consiga arcar com os custos, aqueles que não possuem estas condições se veem obrigados a ocupar locais periféricos. (NASCIMENTO, 2017).

Esta porção da cidade foi a primeira a desenvolver um centro comercial e de serviços, sendo ainda hoje o principal locus na cidade destas atividades. A centralidade exercida pelos objetos geográficos de interesse público, associado ao fluxo constante nesta região, concentraram no bairro 
Centro os investimentos públicos e privados realizados na cidade. Nesta região do espaço urbano também se localizam hospitais e clínicas de saúde, que atraem pacientes não só de Chapecó, mas também dos municípios vizinhos.

Observa-se ao mesmo tempo a existência de elementos dos dois circuitos da economia, que criam materialidades urbanas com características diferentes. Em alguma medida, é possível observar locais onde predominam atividades de cada um destes circuitos; é o caso do camelódromo da cidade, onde concentram-se aspectos do circuito inferior; e do shopping center, onde há majoritariamente representantes de grandes empresas. Entretanto, de modo geral é observável um equilíbrio entre estabelecimentos modernos associados a grandes empresas e estabelecimentos tradicionais de pequenos comerciantes na porção central da cidade. Também nos é sensível que ao longo das avenidas principais concentram-se principalmente representantes de grandes empresas, que ocupam desta posição para promover suas atividades. Enquanto as atividades econômicas de pequenos comerciantes situam-se predominantemente nas vias paralelas (figura 7).

Na figura 8 buscamos representar a distribuição das áreas de comércio e serviços nesta porção do espaço, representando as diferenças de ocupação e densidades. Por tratar-se de um trabalho inicial, a abrangência de cada classe apresentada deve ser discutida para aprimorar-se a representação. Elencamos três setores principais: i) Ao longo da avenida Leopoldo Sander e partes da avenida Fernando Machado (representada em marrom claro): nesta porção concentram-se pequenas e médias indústrias de ramos variados e estabelecimentos de serviços, principalmente associados a veículos; ii) No centro da cidade e ao longo das avenidas principais, como a Fernando Machado e Getúlio Vargas (representada em verde): é a porção de maior densidade comercial e de serviços, onde concentra-se a maioria dos estabelecimentos do circuito superior. Existindo também representantes do circuito inferior; iii) Área adjacente ao centro da cidade (representada em amarelo): trata-se da região onde a densidade de estabelecimentos econômicos é menor, predominando as moradias. Nesta porção existe proporcionalmente mais estabelecimentos que compõe o circuito inferior; porém, também existem representantes de grandes companhias. Vale destacar que Chapecó não é uma cidade planejada de modo a separar no espaço urbano distintas atividades econômicas e áreas de moradias. Sendo neste sentido, que há no interior da cidade a coexistência de distintos estabelecimentos comerciais e habitações no mesmo espaço. 


\section{Revista Cadernos de Economia}

Universidade Comunitária da Região de Chapecó - Unochapecó

Universidade Estadual do Rio Grande do Norte - UERN
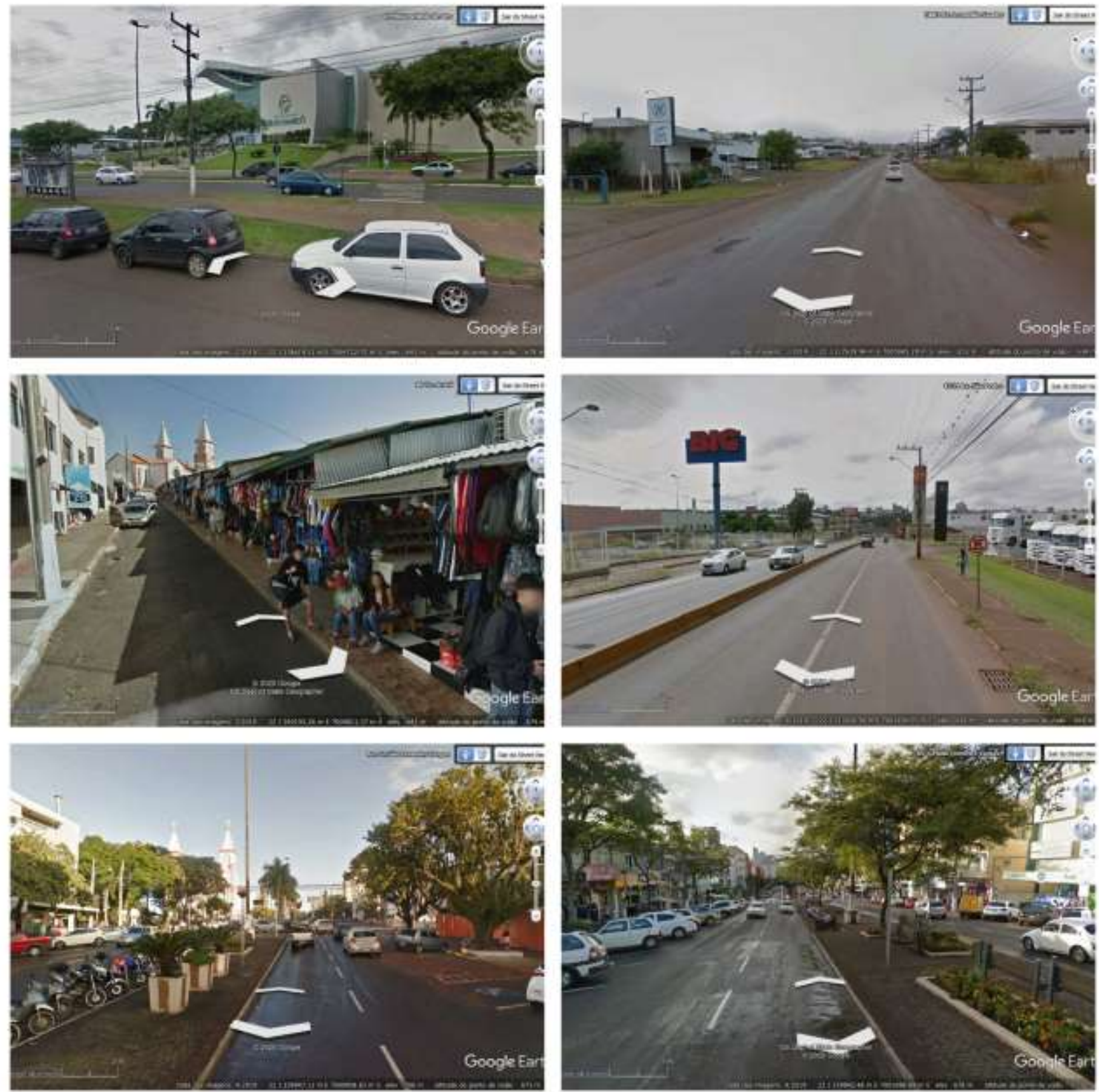

Figura 7: Paisagens do centro comercial e de serviços do Centro e bairros adjacentes. Google Earth, acesso em 05/11/2020. 


\section{Revista Cadernos de Economia}

Universidade Comunitária da Região de Chapecó - Unochapecó

Universidade Estadual do Rio Grande do Norte - UERN

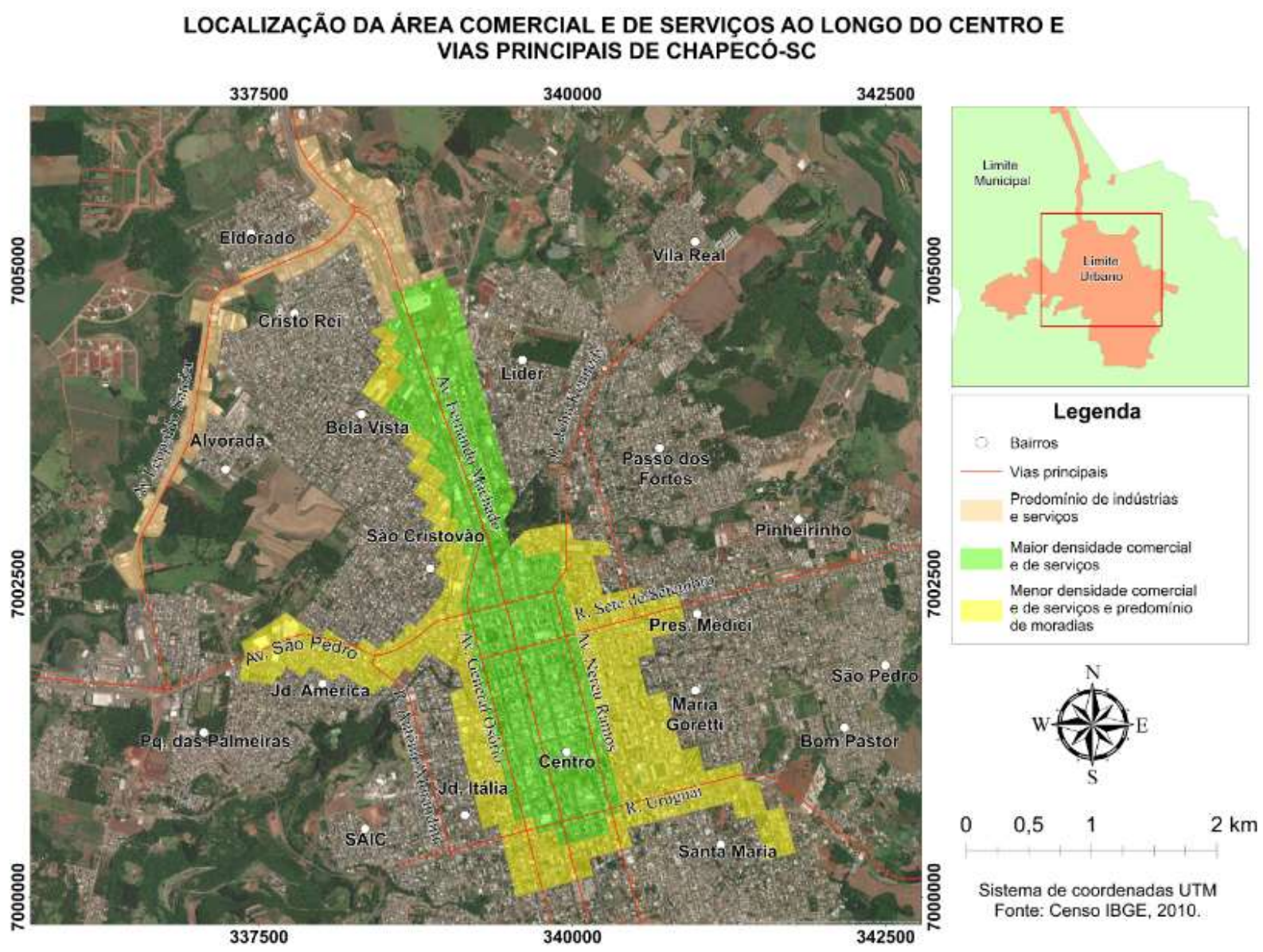

Figura 8: Localização da área comercial e de serviços o longo do centro e vias principais de Chapecó-SC.

\section{CENTRO COMERCIAL E DE SERVIÇOS DO BAIRRO EFAPI}

A área comercial do bairro Efapi é mais recente quando comparada à do Centro. O bairro Efapi tem seus primeiros loteamentos construídos na década 1970, e a partir daí aos poucos começam a surgir estabelecimentos comerciais que se concentram próximos à avenida Atílio Fontana. Este centro comercial direciona-se principalmente para os habitantes do próprio bairro Efapi e bairros vizinhos, que em grande medida são ocupados por trabalhadores das agroindústrias e estudantes universitários que se concentram na região oeste da cidade. O bairro Efapi é historicamente segregado do ponto de vista social e financeiro, existindo áreas de ocupação irregular com infraestruturas precárias. (NASCIMENTO e LEMOS, 2019. NASCIMENTO e KOVALSKI, 2018.).

O centro comercial do bairro Efapi fica próximo a duas universidades (Unochapecó e UFFS) e a cinco grandes indústrias (BRF S.A., dois frigoríficos da Aurora, um silo da Cooperalfa e a 
unidade da Randon em Chapecó). Além de haver também indústrias menores, escolas, órgãos do estado, etc. Circunstância que faz com que a Avenida Atílio Fontana seja muito movimentada, devido a ser a principal via de ligação entre essas áreas e o centro da cidade. Esse constante fluxo de pessoas faz com que os estabelecimentos comerciais que se estabelecem próximo à avenida possuam vantagens locacionais sobre os demais.

A paisagem da Avenida Atílio Fontana é composta por estabelecimentos comerciais aglomerados, aliado a vendedores ambulantes que exercem suas atividades literalmente na rua. A impressão ao se observar este espaço resulta em uma paisagem um tanto confusa, com adaptações estruturais sem haver uma constância e organização no tipo de imóveis avistados. Fato que é singular ao circuito inferior, onde edificações próximas apresentam discrepâncias significativas de estrutura e arquitetura (Figura 9). Percebe-se que a forma de publicidade dos comércios é bastante primitiva, baseado principalmente na conversa, no boca a boca. As estruturas utilizadas para a divulgação das lojas (banners, fachadas, placas; etc) em grande parte encontram-se deterioradas, utilizando técnicas já não mais tão vistas no circuito superior, como letreiros pintados à mão. Alguns comerciantes deste centro também relatam utilizar de panfletos e de divulgação em redes sociais para impulsionar seus serviços. Grande parte dos indivíduos que compões este setor veem as instâncias do estado como adversas, visto que não há políticas públicas destinadas ao auxílio destas atividades e frequentemente a infraestrutura dos estabelecimentos passa por avaliações e adequações exigidas por órgãos de fiscalização.

As lojas que se localizam neste centro adéquam os produtos e serviços para o seu públicoalvo. Visto que a maioria dos moradores que residem no bairro pertencem às classes econômicas menos abastadas, estes não detêm condições financeiras de comprarem produtos de grandes marcas, que possuem um preço elevado quando comparado a produtos inferiores. Pensando em relações entre os dois circuitos, as lojas deste centro utilizam de máquinas de cartão de crédito, as mercadorias utilizadas em sua grande maioria são fornecidas por grandes empresas e também é observável que empresas do circuito superior utilizam da área para comercializar seus produtos e serviços, adequando suas mercadorias ao poder de compra da população.

Devemos destacar também as grandes indústrias que se encontram na região oeste da cidade, que estão relacionadas principalmente à produção de carnes. As mesmas possuem uma infraestrutura moderna que é característica deste setor, empregando equipamentos altamente tecnológicos e mão de obra em alguma medida qualificada para trabalhar com os mesmos. Entretanto, a proporção entre mão de obra qualifica e não qualifica é desigual, havendo muito mais 


\section{Revista Cadernos de Economia}

Universidade Comunitária da Região de Chapecó - Unochapecó

Universidade Estadual do Rio Grande do Norte - UERN

trabalhadores não qualificados. Neste sentido, percebesse a presença simultânea entre elementos do circuito inferior e superior na materialidade do bairro Efapi, o que resulta em uma paisagem com características complexas (figura 10).
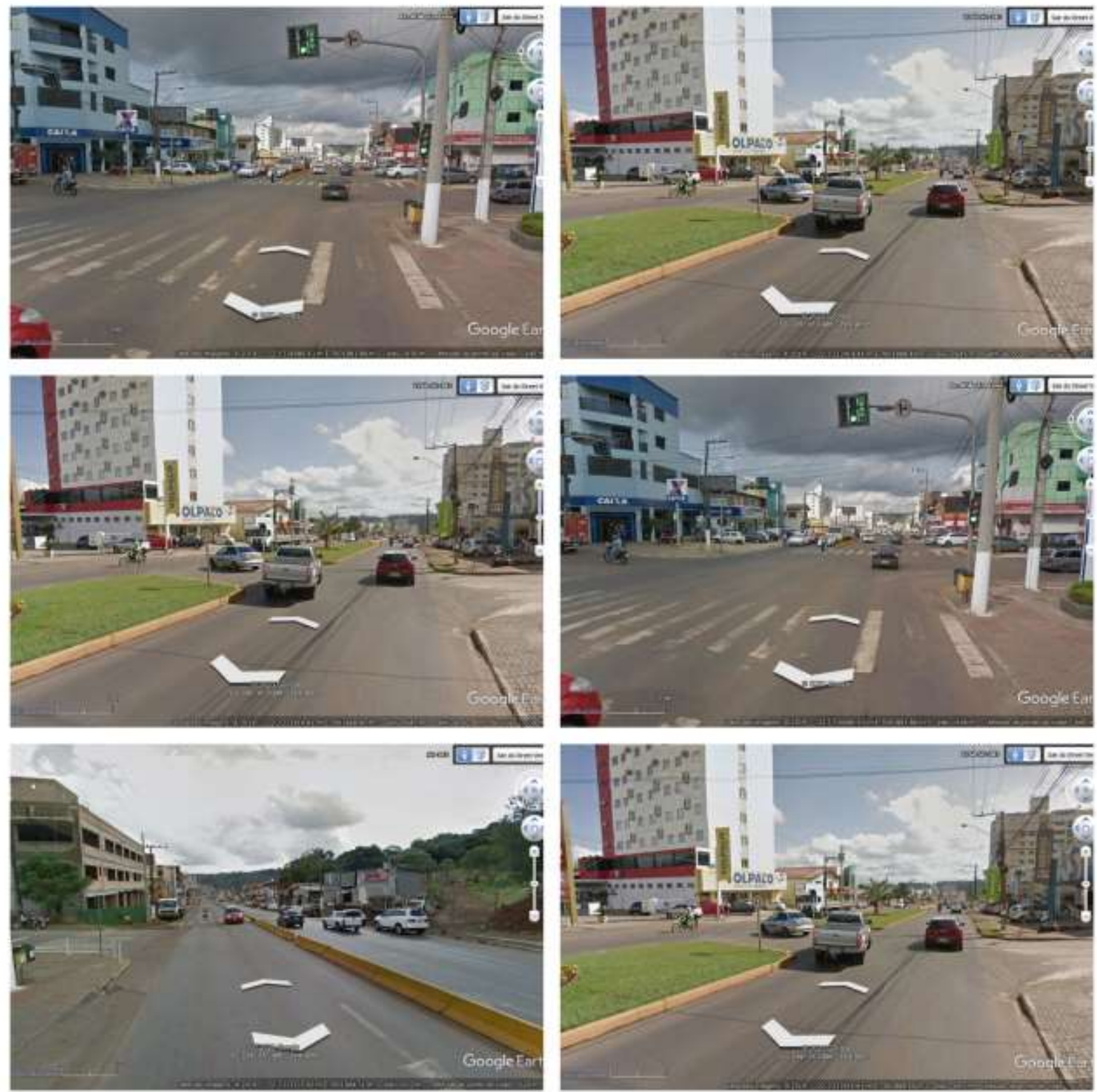

Figura 9: Paisagens do centro comercial e de serviços do bairro Efapi. Google Earth, acesso em 05/11/2020. 


\section{Revista Cadernos de Economia}

Universidade Comunitária da Região de Chapecó - Unochapecó

Universidade Estadual do Rio Grande do Norte - UERN
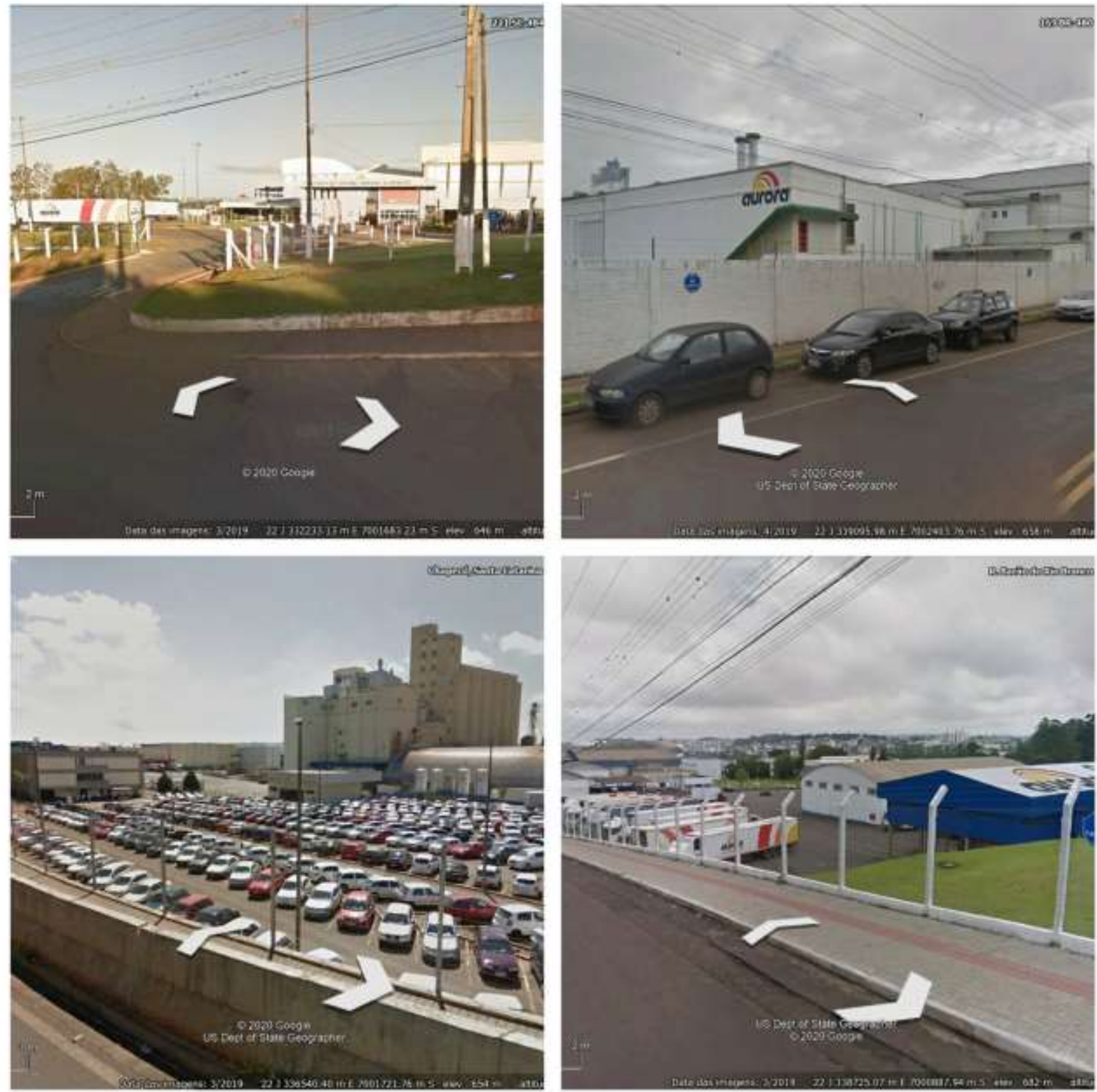

Figura 10: Paisagens das agroindústrias. Google Earth, acesso em 05/11/2020.

Na figura 11 buscamos espacializar a localização dos estabelecimentos comerciais e de serviços do bairro Efapi, percebesse que estes concentram-se sobretudo ao longo da avenida Atílio Fontana. Neste centro comercial os elementos do circuito inferior são predominantes, mas também existem estabelecimentos característicos do circuito superior, tratando-se neste sentido de uma estratégia deste setor visando estabelecer-se e ampliar suas atividades nesta área que é ocupada historicamente por pequenos empresários. 
Revista Cadernos de Economia

Universidade Comunitária da Região de Chapecó - Unochapecó

Universidade Estadual do Rio Grande do Norte - UERN

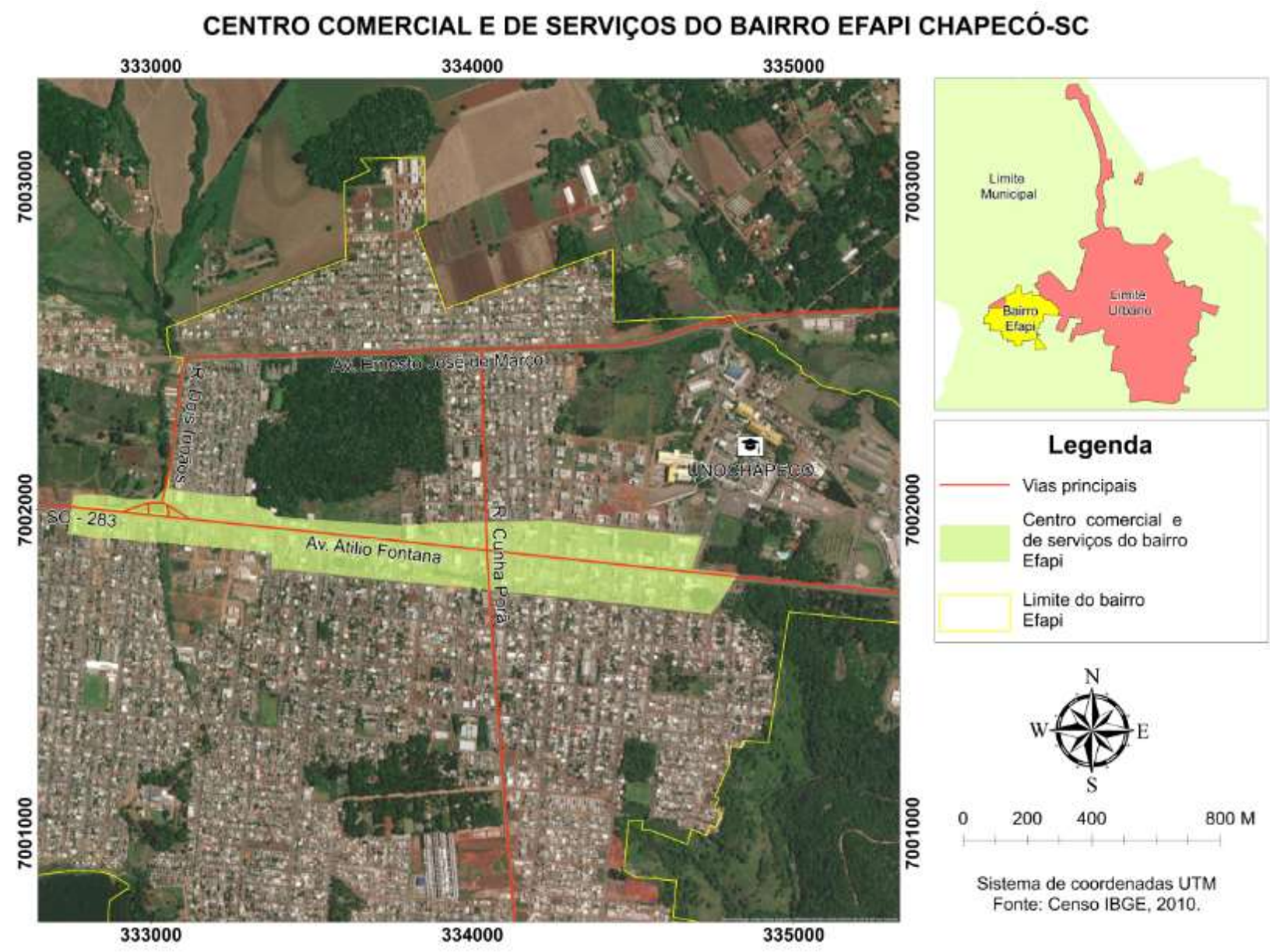

Figura 11: Centro comercial e de serviços do bairro Efapi Chapecó-SC.

\section{O DISTRITO INDUSTRIAL FLÁVIO BALDISSERA}

O distrito industrial Flávio Baldissera localiza-se ao sul do limite urbano chapecoense, próximo à BR-480. Este distrito foi criado a partir de uma lei municipal de novembro de 2000 com o objetivo de sanar a demanda por um espaço destinado às empresas emergentes do município. Neste espaço percebemos uma infraestrutura bem estabelecida, com ruas asfaltadas e amplo espaço para os estabelecimentos industriais desenvolverem em plenitude suas atividades. A arquitetura dos estabelecimentos em questão é característica das indústrias modernas, onde também são empregados nas atividades maquinários com alto grau de tecnologia (figura 12). Grande parte das indústrias que estão estabelecidas neste terreno atuam no ramo metalmecânico, fornecendo equipamentos para as atividades agroindustriais que são amplamente difundias no oeste catarinense. Neste sentido, fornecem um serviço de complementariedade industrial de grande importância 
Vale destacar que a posição onde está estabelecido o terreno é estratégica do ponto de vista da mobilidade de transportes. O acesso Fidalis Grando que liga o distrito a BR-480 é asfaltado, o que fornece fluidez para as empresas escoarem seus produtos. A BR-480 é uma via de trânsito rápido que torna possível que as empresas do distrito distribuam facilmente seus produtos para o oeste catarinense, noroeste do Rio Grande do Sul e sudoeste do Paraná. A fluidez dos meios de transporte é um importante fator locacional para este tipo de empresa, visto que frequentemente precisam enviar suas mercadorias para lugares longínquos. Toda a infraestrutura básica necessária para o trabalho das indústrias na área foi previamente elaborada pela prefeitura (pavimentação das ruas e do acesso ao distrito, fornecimento de água e energia elétrica, terraplanagem dos terrenos; etc.), demonstrando a atenção que o estado oferece a esse setor. 


\section{Revista Cadernos de Economia}

Universidade Comunitária da Região de Chapecó - Unochapecó

Universidade Estadual do Rio Grande do Norte - UERN
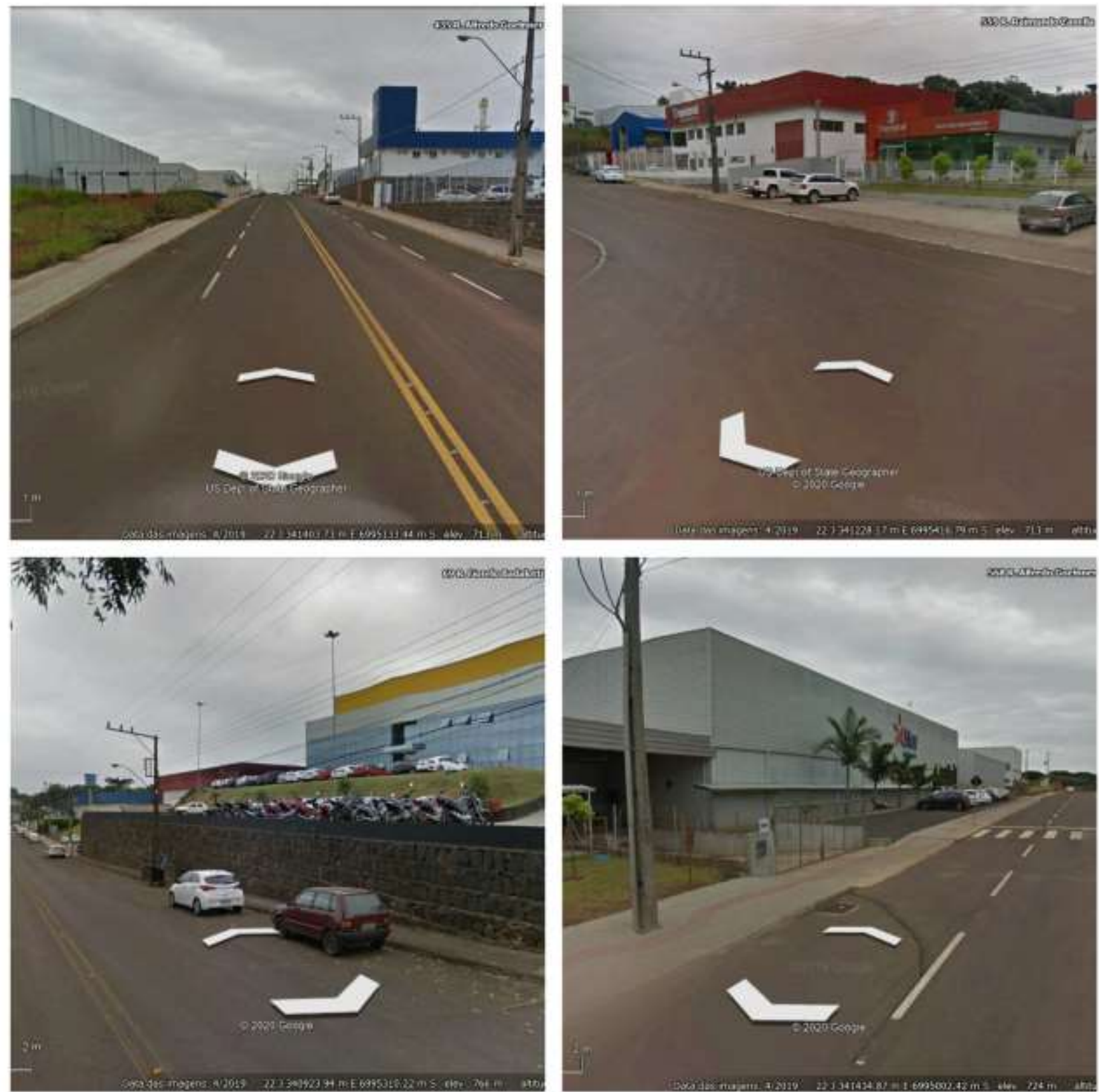

Figura 12: Paisagens do distrito industrial Flávio Baldissera. Google Earth, acesso em 05/11/2020. 


\section{Revista Cadernos de Economia}

Universidade Comunitária da Região de Chapecó - Unochapecó

Universidade Estadual do Rio Grande do Norte - UERN

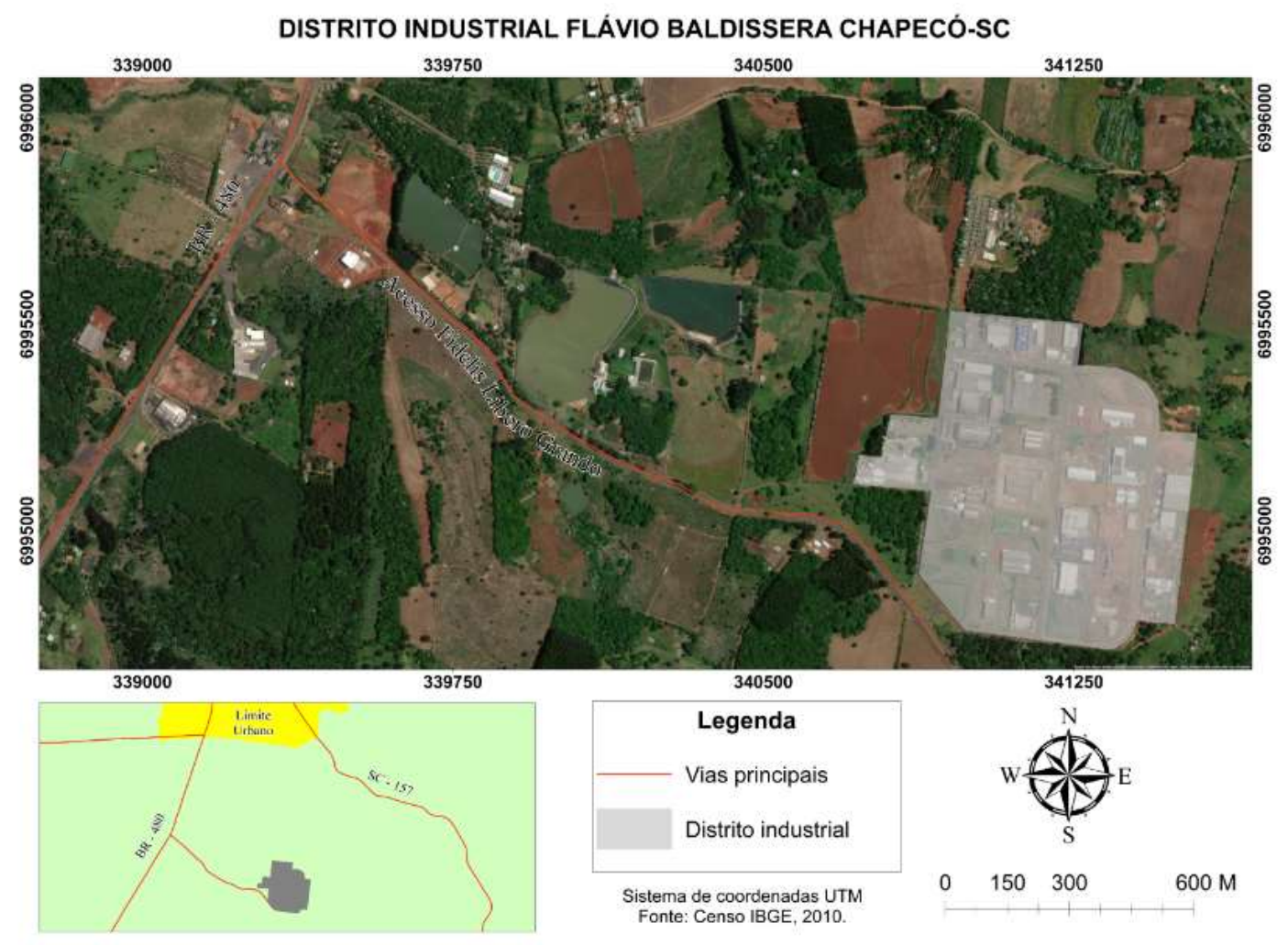

Figura 13: Distrito industrial Flávio Baldissera Chapecó-SC

Na figura 13 é observável a localização do terreno e as vias de acesso que se ligam ao mesmo. Vale destacar que na área do distrito ainda há espaços vagos que não estão sendo ocupados, tornando possível que novas empresas possam locar suas atividades no local e ampliar a variedade de serviço e o número de postos de trabalho.

\section{CONSIDERAÇÕES FINAIS}

Pelo que apresentamos ao longo do trabalho, percebemos que a teoria dos dois circuitos da economia urbana mesmo quarenta anos após ser proposta ainda é muito útil para descrever a disposição dos estabelecimentos econômicos em Chapecó e as estratégias locacionais dos mesmos. A realidade da cidade e do Brasil como um todo é a característica dos países subdesenvolvidos, com grandes desigualdades econômico-sociais e de incidência das estruturas básicas. O que resulta em uma configuração de espaço que lembra um palimpsesto, com objetos com graus de evolução técnica diferente ocupando o mesmo local.

O padrão de ocupação que percebemos resulta em estabelecimentos pertencentes ao circuito superior ocupando geralmente as melhores posições, em locais próximos a vias que fornecem 
Revista Cadernos de Economia

Universidade Comunitária da Região de Chapecó - Unochapecó

Universidade Estadual do Rio Grande do Norte - UERN

fluidez (no caso de indústrias) e nas avenidas onde circulam muitas pessoas (no caso de comércios e serviços). Os estabelecimentos se acumulam principalmente no centro da cidade. Há também o caso do shopping center, que merece uma análise especial devido a ser um estabelecimento privado onde se concentram muitas lojas de grandes empresas. Enquanto os estabelecimentos do circuito inferior concentram-se sobretudo próximo a vias de grande fluxo, geralmente ocupando locais secundários em relação aos estabelecimentos do circuito superior. $\mathrm{O}$ centro comercial do bairro Efapi é um exemplo de centro comercial marginal localizado em uma região periférica densamente ocupada dentro do espaço urbano. Onde sobressaem a presença de pequenos comerciantes e prestadores de serviços que destinam seu trabalho a uma população que não possui grandes recursos.

Ao final deste trabalho, defendemos que o estado promova políticas públicas que favoreçam também os integrantes do circuito inferior. Visto que este grupo possui grande capacidade de gerar empregos e renda. Historicamente a relação destes vem sendo conflituosa, onde o estado é visto como um dificultador das atividades. Entretanto, o monitoramento dos estabelecimentos por meio de fiscalizações de órgãos do estado também é importante para promover a segurança física e de renda dos trabalhadores e consumidores, além de resultar em importantes informações para a promoção de políticas públicas.

\section{REFERÊNCIAS}

DALMORA, Tiago; SCHERMA, Ricardo. ESPECIALIZAÇÃO REGIONAL E PRODUÇÃO AGROALIMENTAR: o circuito espacial produtivo avícola no território brasileiro. IX Jornada de Iniciação Científica e Tecnológica - IX Jic. Chapecó-SC. set. 2019.

FACCO, J. et al. Agroindustrialização e urbanização de Chapecó - SC (1950 - 2010): uma visão sobre os impactos e conflitos urbanos e ambientais. Revista de Desenvolvimento Regional, Santa Cruz do Sul, p. 187-215, jun. 2014.

IBGE - INSTITUO BRASILEIRO DE GEOGRAFIA E ESTATÍSTICA. Regiões de influência das Cidades: 2018. Rio de Janeiro: IBGE, 2020

KAISER, J. Guerra do contestado: a revolta dos caboclos no sertão catarinense. 2. ed. Florianópolis: Letras Brasileiras, 2012.

MORETTO, S. P.; BRANDT, M. Das pequenas produções à agroindústria: suinocultura e transformações na paisagem rural em Chapecó, SC. Tempo e Argumento, v. 11, n. 26, p. 229-254, abr. 2019. 
NASCIMENTO, E. A segregação socioespacial em Chapecó: formação histórico-geográfica e tendências contemporâneas. In: NASCIMENTO, E.; VILLELA, A. L. V. Chapecó em foco: textos e contextos sobre o espaço urbano-regional. São Carlos: Pedro \& João Editores, 2017. p. 105-154.

NASCIMENTO, E. Chapecó: evolução urbana e desigualdades socioespaciais. In: BRANDT, M.; NASCIMENTO, E. (Orgs.). Oeste de Santa Catarina: território, ambiente, paisagem. São Carlos: Pedro \& João, 2015. p. 97-154.

NASCIMENTO, Ederson do; KOVALSKI, Daniela. Contrastes de uma "cidade dentro da cidade": as desigualdades socioespaciais no bairro Efapi, em Chapecó. In: NASCIMENTO, Ederson do. Território e sociedade: novos estudos sobre Chapecó e região. Chapecó: Novas Edições Acadêmicas, 2018. Cap. 15. p. 323-344.

NASCIMENTO, E; LEMOS, J. H. Territórios urbanos precários: uma análise da cidade de Chapecó, SC, Brasil. Terr@Plural, v. 14, p. 1-23, e2013362, 2020.

RADIN, José Carlos. Um olhar sobre a colonização da Fronteira Sul. In: RADIN, José Carlos; VALENTINI, Delmir José; ZARTH, Paulo A.. HISTÓRIA DA FRONTEIRA SUL. Chapecó: Editora da Uffs, 2015. Cap. 8. p. 146-166.

SANTOS, Milton. O espaço dividido: Os dois circuitos da economia urbana dos países subdesenvolvidos. Rio de Janeiro: Livraria Francisco Alves Editora S.a., 1979. 345 p.

SANTOS, Milton. Os dois circuitos da economia urbana e suas implicações espaciais. In: SANTOS, Milton. Da totalidade ao lugar. São Paulo: Edusp, 2014. Cap. 6. p. 93-113.

VILLELA, A. L. V. et al. Centralidade no Oeste Catarinense: o papel de Chapecó. In: OLIVEIRA, H. C. M. et al. (Orgs). Cidades médias e região. São Paulo: Cultura Acadêmica, 2017. p. 101-138. 